\title{
Bioprospecting insecticidal compounds from plants native to Mato Grosso do Sul, Brazil
}

\author{
Antonio P. Souza ${ }^{1,2}$, Maria R. Marques ${ }^{1}$, Talal S. Mahmoud ${ }^{1}$, Bruno A. Caputo ${ }^{1}$, Gabriel M. Canhete ${ }^{1}$, \\ Carla B. Leite ${ }^{1}$ e Dênis P. de Lima ${ }^{1}$
}

Received: July 11, 2007. Accepted: April 25, 2008

\begin{abstract}
RESUMO - (Bioprospecção de substâncias inseticidas de plantas nativas de Mato Grosso do Sul, Brasil). No presente trabalho foi avaliada a atividade inseticida de extratos de limbos foliares de Tapirira guianensis Aubl. (Anacardiaceae), Attalea phalerata (Mart. ex Spreng.) Burret (Arecaceae), Eugenia uniflora L. (Myrtaceae) e Gomphrena elegans Mart. (Amaranthaceae) e de caules de Myracrodruon urundeuva Allemão (Anacardiaceae). Foram testados quatro extratos e 18 frações, com diferentes polaridades. Dez gramas de grãos de trigo foram pulverizados com $1 \mathrm{~mL}$ de cada extrato a $10 \%(\mathrm{p} / \mathrm{v})$. Após a evaporação do solvente a $38^{\circ} \mathrm{C}$, os grãos foram acondicionados em recipientes juntamente com 20 indivíduos adultos de Sitophilus zeamais não sexados, com 10 a 20 dias de idade. As avaliações foram feitas no quinto e no décimo dia, contando-se o número de insetos mortos e descartando-os. Os extratos foliares de G. elegans ocasionaram mortalidade de $27 \%$ a $60 \%$ até o quinto dia, enquanto os demais extratos testados, quando ativos, não ultrapassaram a faixa de $20 \%$ de mortalidade no mesmo período. No décimo dia, os extratos mais ativos foram o proveniente de A. phalerata (hexânico, $36,5 \%$ ) e todos os de G. elegans ( $52 \%$ a $80,5 \%$ ), enquanto os demais extratos causaram até $30 \%$ de mortalidade.
\end{abstract}

Palavras-chave: metabólitos secundários, plantas inseticidas, gorgulho-do-milho, Sitophilus zeamais

\begin{abstract}
Bioprospecting insecticidal compounds from plants native to Mato Grosso do Sul, Brazil). This paper reports on an evaluation of the insecticidal activity of extracts prepared from leaves of Tapirira guianensis Aubl. (Anacardiaceae), Attalea phalerata (Mart. ex Spreng.) Burret (Arecaceae), Eugenia uniflora L. (Myrtaceae), and Gomphrena elegans Mart. (Amaranthaceae) and from stems of Myracrodruon urundeuva Allemão (Anacardiaceae). Four extracts and 18 fractions with a range of polarities were tested. Tengram batches of wheat grains were each nebulized with $1 \mathrm{~mL}$ of a separate extract at $10 \% \mathrm{w} / \mathrm{v}$. After solvent evaporation at $38{ }^{\circ} \mathrm{C}$, the grains were placed into flasks along with 20 unsexed 10- to 20-day old adult individuals of Sitophilus zeamais. The assessment was carried out on the fifth and tenth day by counting and discarding the dead insects. Leaf extracts of G. elegans showed an insecticidal effect ranging from $27 \%$ to $60 \%$ by the fifth day, whereas the effect of the remaining extracts tested (if active at all) did not exceed $20 \%$ in the same period. By the tenth day, the most active extracts were those of A. phalerata (hexanic, 36.5\%) and all those of G. elegans $(52-80.5 \%)$, whereas the effect of the other extracts did not exceed $30 \%$.
\end{abstract}

Key words: secondary metabolites, insecticidal plant, maize weevil, Sitophilus zeamais

\section{Introduction}

From the academic point of view, plants represent a vast storehouse of potentially useful natural products, and in fact many laboratories worldwide have screened thousands of species of higher plants, not only in search of pharmaceuticals, but also of pest control products (Van Beek \& Breteler 1993). Botanical insecticides have long been heralded as attractive alternatives to synthetic chemical insecticides for pest management because botanicals reputedly pose little threat to the environment or to human health. The body of scientific literature documenting bioactivity of plant derivatives on arthropod pests continues to expand, yet only a handful of botanicals are currently used in agriculture in the industrialized world, and few are the prospects for commercial development of new botanical products (Isman 2006).

A major motivation to promote research on and use of pest control methods at low environmental cost is the demand of consumers searching for healthier products, a social behavior reflected in product registration laws that favor the use of low-cost insecticides having minimal environmental impact. Another reason is that botanicals have been a focus of interest of chemists and biologists because of their structural complexity, potency, and selectivity. Pyrethrum has been the most important botanical for almost two centuries (Isman 2000). Rotenone, ryanodine, veratridine, and azadirachtin, active ingredients of ryania (Ryania speciosa), sabadilla (Schoenocaulon officinale), and

\footnotetext{
1 Universidade Federal de Mato Grosso do Sul, Department of Morphophysiology, Laboratory of Biochemistry, C. Postal 549, 79070-900 Campo Grande, MS, Brasil

2 Corresponding Author: apsouza@nin.ufms.br, apsouza2004@ hotmail.com
} 
neem (Azadirachta indica), respectively, have been widely used for their effectiveness and low toxicity to mammals. The most vigorous development program in recent years has been that for expanded uses of neem seed extract (Casida \& Quistad 1998; Isman 2000).

Over 200,000 metabolites are currently known, which are estimated to account for roughly $10 \%$ of the possible number of these compounds in nature (Croteau et al. 2000; Dixon \& Strack 2003). Their structures, functions, and uses have not been sufficiently evaluated. In general these compounds do not take part in basic metabolism, but are essential to the plant by mediating plant-plant and plant-herbivore interactions. They also play a role in aspects such as flower coloration and scent and food color and taste, in addition to granting resistance against pests and diseases (Verpoorte et al. 1999; Dixon 2001).

Plants native to the Pantanal and Cerrado regions of the southwestern state of Mato Grosso do Sul, in Brazil, have been poorly studied, despite being a rich source of promising molecules for insect control. To evaluate the insecticidal effect of these plants we have selected the maize weevil Sitophilus zeamais Motsch. (Curculionidae) as a model, since it is the main insect pest of stored wheat in Brazil. Furthermore, it has a great number of hosts, high biotic potential, and high capacity for grain mass penetration and cross-infestation, causing damage particularly to corn, rice, and wheat stocks (Santos et al. 1990; Gallo et al. 2002). These features led us to select several plant species in order to prepare extracts and carry out an evaluation of their insecticidal activity against $S$. zeamais.

\section{Material and methods}

Biological material - The colony of S. zeamais on wheat grains was kept at $25 \pm 2.2{ }^{\circ} \mathrm{C}$, at relative humidity of $60 \pm 10 \%$ and natural photoperiod. The experiments were conducted under the same conditions. Gomphrena elegans Mart. (Amaranthaceae) was collected from the rivers Sucuri and Baía Bonita, in Bonito county, Mato Grosso do Sul. Tapirira guianensis Aubl. (Anacardiaceae), Attalea phalerata (Mart. ex Spreng) Burret (Arecaceae), Eugenia uniflora L. (Myrtaceae) and Myracrodruon urundeuva Allemão (Anacardiaceae) were collected from the UFMS Biological Reserve, located in Cerrado landscape. Plant identification was based on the collected material. Exsiccates were deposited in the UFMS Herbarium. Selection of species, extracts, and fractions was based on previous chemical ecology studies conducted at the UFMS Laboratory of Biochemistry, where additional biological activities had been tested. The present investigation is an effort to further understand the ecology of these native plants.

Preparation of plant extracts - The solvents used in extraction, partition, and chromatography procedures were of analytical grade.

Plant material was collected in May 2006. Plants exhibiting natural injury were selected for leaf and stem collection. Each batch (10 g of leaves and stems) was air-dried, cut in small pieces, and then crushed in a Wileytype mill. The resulting material was extracted with ethanol for seven days, with occasional stirring, and filtrated. The filtrate was concentrated by rotaevaporation and placed in a desiccator for dehydration. As a semipurification step, it was submitted to liquid-liquid partition with solvents of increasing polarity. Choice of partition methods was based on pilot experiments conducted for each species, applying methodology adapted from Cechinel Filho \& Yunes (1998).

Leaves of T. guianensis and stems of M. urundeuva were submitted to partition with hexane, dichloromethane, ethyl acetate, and n-butanol. This method usually yields a final residue containing mostly polar compounds (the so-called polar fraction). Leaves of Attalea phalerata (Mart. ex Spreng) Burret and G. elegans were submitted to partition with hexane, dichloromethane, ethyl acetate, and hydroalcoholicm a method that does not yield an insoluble residue at the end of partition. Because the crude extract of E. uniflora leaves was not subjected to partition, only the ethanolic extract of this species was tested.

Insecticidal activity assay - Wheat grains were nebulized in a laminar-flow hood using a glass nebulizer coupled to a vacuum pump. The weight of the extracts and phases employed in the assays are discriminated in Table 1. The extracts were diluted with $10 \mathrm{~mL}$ of an appropriate solvent for each $100 \mathrm{~g}$ of wheat grains. Preliminary tests were conducted to evaluate the insecticidal effect of the solvents alone, revealing that when wheat grains were left for about $72 \mathrm{~h}$ in a hood at $38{ }^{\circ} \mathrm{C}$ after solvent spraying (ethanol, n-butanol, ethyl acetate, dichloromethane, hexane), insect survival was not affected. A temperature of $38{ }^{\circ} \mathrm{C}$ was chosen because it preserves the chemical characteristics of organic compounds present in vegetal extracts. The grains were subjected to the same treatment, whether with extracts or fractions.

After drying, the grains were transferred to plastic round-bottom flasks ( $10 \mathrm{~g}$ per flask). Control flasks held untreated grains. Twenty 10- to 20-day-old adult specimens of $S$. zeamais (unsexed) were placed in each flask. Evaluations were carried out on the fifth and tenth day by counting the number of dead insects and discarding them. The extract fractions were distributed 
1138 Souza, Marques, Mahmoud, Caputo, Canhete, Leite \& Lima: Bioprospecting insecticidal compounds from...

Table 1. Plant extracts tested for insecticidal activity against Sitophilus zeamais.

\begin{tabular}{|c|c|c|c|c|c|c|c|}
\hline \multirow[t]{3}{*}{ Species (plant part) } & \multicolumn{7}{|c|}{ Weight $(\mathrm{g})$} \\
\hline & \multirow[b]{2}{*}{$\begin{array}{c}\text { Ethanolic } \\
\text { extract }\end{array}$} & \multicolumn{6}{|c|}{ Phase } \\
\hline & & $\begin{array}{l}\text { Dichloro } \\
\text { methane }\end{array}$ & $\begin{array}{l}\text { Ethyl a } \\
\text { cetate }\end{array}$ & n-Butanol & Hexanic & $\begin{array}{l}\text { Hydro } \\
\text { alcoholic }\end{array}$ & $\begin{array}{l}\text { Polar } \\
\text { fraction }\end{array}$ \\
\hline Tapirira guianensis (leaves) & - & 0.032 & 0.170 & 0.580 & 0.300 & - & 0.015 \\
\hline Attalea phalerata (leaves) & 2.544 & 0.760 & 0.700 & - & 1.300 & 0.060 & - \\
\hline Eugenia uniflora (leaves) & 0.420 & - & - & - & - & - & - \\
\hline Gomphrena elegans (leaves) & 0.920 & 0.090 & 0.110 & - & 0.380 & 0.256 & - \\
\hline Myracrodruon urundeuva (stems) & 1.740 & 0.025 & 0.360 & 0.845 & 0.260 & - & 0.005 \\
\hline
\end{tabular}

according to a random experimental planning of ten repetitions for each treatment. To meet analysis purposes, data from the first to the tenth day were cumulative. The data were subjected to variance analysis (F test). When a significant difference was detected between means at $5 \%$ level of significance, a supplementary analysis was performed by comparing means using Tukey's test.

\section{Results and discussion}

Experiments for evaluating the effect that plant extracts have on the mortality of adult coleopters usually do not extend beyond the fifth day (Tapondjou et al. 2002; Mazzonetto \& Vendramim 2003; Silva et al. 2003; Tavares \& Vendramim 2005). In the present investigation, the effect on mortality was actually observed from the fifth day, but discrimination among the various fractions was facilitated by collecting data until the tenth day (Table 2).

Of the T. guianensis preparations tested, only the n-butanol fraction from leaves affected the survival of $S$. zeamais adults by the fifth day. By the tenth day the dichloromethane, hexane, and polar fractions also caused mortality (Table 2, test 1). Even though some extracts led to insect death, the effect was below $20 \%$. No data were found in the literature concerning the insecticidal activity of T. guianensis on other insects. The plant species, however, contains tannins, flavonoids, and terpenoids (Jardim et al. 2005), which are compounds associated with insect antifeedant activity (Sharma \& Norris 1994; Simmonds 2001; Park et al. 2000; Calcagno et al. 2002; Morimoto et al. 2002; Piubelli et al. 2003).

With regard to $A$. phalerata leaf extracts, the hexanic phase led to $19.0 \%$ and $36.5 \%$ of mortality by the fifth and tenth day, respectively. The other fractions showed very low insecticidal activity (Table 2, tests 1 and 2). In addition to its medicinal properties, the species is attractive to bees, is grazed by cattle, and has edible fruits and seeds (Guarim Neto \& Morais

\section{3; Pott \& Pott 2003).}

The ethanolic extract of $E$. uniflora leaves did not exhibit insecticidal activity on $S$. zeamais (Table 2, test 2), although tannins and alkaloids have already been detected in the leaves of this plant (Lee et al. 1997; Matsumura et al. 2000). Alkaloids are classified as qualitative toxics, as they act even in small amounts and are deleterious to most insects (Strong et al. 1984; Mello \& Silva Filho 2002).

Of the M. urundeuva preparations, the effects of the n-butanol phase and the polar fraction on the insects differed from the controls starting on the fifth day. By the tenth day all treatments differed from controls, but values were below 30\% (Table 2, test 3), despite the presence of tannins and alkaloids in this species (Cavalcante et al. 2006).

From the fifth day onward all fractions prepared from leaves of G. elegans had effects that diverged from controls. The ethyl acetate phase was particularly noteworthy, as it led to a $60 \%$ rate of mortality. By the tenth day the rate for the hydroalcoholic phase $(76 \%)$ was similar to that for ethyl acetate $(80.5 \%)$. The dichloromethane and hexanic phases and the ethanolic extract caused an intermediate level of mortality $(71.5 \%$, $69 \%$, and 52\%, respectively) (Table 2, test 4). G. elegans leaves are known to contain saponins and coumarins (Saito et al. 2004). Coumarins have insecticidal effects similar to that of rotenone, generating transport blockage of electrons during the respiratory process (Nicholson et al. 1995).

Gomphrena elegans is an aquatic plant native to the Bonito region of Mato Grosso do Sul. Its overgrowth, mainly on shores of the rivers Sucuri and Baía Bonita, has been an object of concern to environmentalists. No data are available in the literature on the phytochemical profile of the species. Considering its high capacity for survival and reproduction, which allow it to compete successfully with other aquatic species, G. elegans may have genetic potential to produce defense compounds against a vast range of herbivores. 
Table 2. Adult mortality (\%) by the fifth and tenth day in Sitophilus zeamais feeding on wheat grains treated with extracts and fractions prepared from plants native to Mato Grosso do Sul, Brazil.

\begin{tabular}{|c|c|c|}
\hline \multirow[t]{2}{*}{ Treatment } & \multicolumn{2}{|c|}{ Mortality* } \\
\hline & $5^{\text {th }}$ day & $10^{\text {th }}$ day \\
\hline \multicolumn{3}{|c|}{ Test $1\left(\mathrm{~F}_{7,79}=17.20, \mathrm{P}=0.0001\right)$} \\
\hline \multicolumn{3}{|c|}{ Leaves of Tapirira guianensis } \\
\hline N-butanol & $12.00 \pm 04.83 \mathrm{a}$ & $18.00 \pm 06.32 \mathrm{a}$ \\
\hline Dichloromethane & $05.50 \pm 04.38 \mathrm{~b}$ & $12.50 \pm 05.40 a b c$ \\
\hline Hexanic & $05.00 \pm 04.71 \mathrm{~b}$ & $09.50 \pm 06.85 \mathrm{bc}$ \\
\hline Polar fraction & $04.50 \pm 04.38 b$ & $08.50 \pm 04.12 b c$ \\
\hline Ethyl acetate & $01.00 \pm 02.11 \mathrm{~b}$ & $05.00 \pm 04.71 \mathrm{~cd}$ \\
\hline \multicolumn{3}{|c|}{ Leaves of Attalea phalerata } \\
\hline Ethanolic & $04.50 \pm 05.50 \mathrm{~b}$ & $13.50 \pm 07.09 \mathrm{ab}$ \\
\hline Ethyl acetate & $04.50 \pm 04.97 \mathrm{~b}$ & $05.50 \pm 05.50 \mathrm{~cd}$ \\
\hline Control & $01.00 \pm 02.11 \mathrm{~b}$ & $01.00 \pm 02.11 \mathrm{~d}$ \\
\hline \multicolumn{3}{|c|}{ Test $2\left(\mathrm{~F}_{4,49}=47.55, \mathrm{P}=0.0001\right)$} \\
\hline \multicolumn{3}{|c|}{ Leaves of Attalea phalerata } \\
\hline Hexanic & $19.00 \pm 18.97 \mathrm{a}$ & $36.50 \pm 20.15 \mathrm{a}$ \\
\hline Dichloromethane & $07.00 \pm 05.87 \mathrm{~b}$ & $10.50 \pm 09.26 \mathrm{~b}$ \\
\hline Hydroalcoholic & $03.00 \pm 07.89 \mathrm{~b}$ & $05.50 \pm 08.32 \mathrm{bc}$ \\
\hline \multicolumn{3}{|c|}{ Leaves of Eugenia uniflora } \\
\hline Ethanolic & $05.00 \pm 08.50 \mathrm{~b}$ & $08.00 \pm 10.50 \mathrm{bc}$ \\
\hline Control & $01.00 \pm 02.11 \mathrm{~b}$ & $01.00 \pm 02.11 \mathrm{c}$ \\
\hline \multicolumn{3}{|c|}{ Test $3\left(\mathrm{~F}_{6,69}=5.76, \mathrm{P}=0.0001\right)$} \\
\hline \multicolumn{3}{|c|}{ Stems of Myracrodruon urundeuva } \\
\hline N-butanol & $15.00 \pm 09.72 \mathrm{a}$ & $28.50 \pm 16.84 \mathrm{a}$ \\
\hline Polar fraction & $13.50 \pm 13.34 \mathrm{a}$ & $27.50 \pm 19.61 \mathrm{a}$ \\
\hline Hexanic & $12.50 \pm 09.79 a b$ & $24.50 \pm 15.71 \mathrm{ab}$ \\
\hline Ethanolic & $12.00 \pm 10.85 a b$ & $18.00 \pm 15.13 \mathrm{ab}$ \\
\hline Ethyl acetate & $07.50 \pm 12.96 a b$ & $18.00 \pm 22.88 \mathrm{ab}$ \\
\hline Dichloromethane & $09.00 \pm 09.66 \mathrm{ab}$ & $14.00 \pm 10.22 \mathrm{~b}$ \\
\hline Control & $01.00 \pm 02.11 \mathrm{~b}$ & $01.00 \pm 02.11 \mathrm{c}$ \\
\hline \multicolumn{3}{|c|}{ Test $4\left(\mathrm{~F}_{5,59}=42.34, \mathrm{P}=0.0001\right)$} \\
\hline \multicolumn{3}{|c|}{ Leaves of Gomphrena elegans } \\
\hline Ethyl acetate & $60.00 \pm 08.82 \mathrm{a}$ & $80.50 \pm 10.92 \mathrm{a}$ \\
\hline Hydroalcoholic & $39.00 \pm 08.76 \mathrm{~b}$ & $76.00 \pm 09.66 \mathrm{a}$ \\
\hline Dichloromethane & $33.50 \pm 04.74 b$ & $71.50 \pm 07.47 \mathrm{ab}$ \\
\hline Hexanic & $41.50 \pm 07.84 b$ & $69.00 \pm 06.99 a b$ \\
\hline Ethanolic & $27.00 \pm 04.22 \mathrm{~b}$ & $52.00 \pm 09.78 \mathrm{ab}$ \\
\hline Control & $03.00 \pm 02.58 \mathrm{c}$ & $03.50 \pm 03.38 \mathrm{c}$ \\
\hline
\end{tabular}

* Means followed by the same letter in the same column do not differ significantly (Tukey's test, $\mathrm{P} \geq 0.05$ ).

Although T. guianensis, A. phalerata, and $M$. urundeuva exhibited some insecticidal effect on S. zeamais, G. elegans was the most promising species, with an insecticidal effect of up to $80 \%$, a finding that may help to explain its successful establishment in the field. Further studies using additional fractions prepared from this last species are warranted, so that its insecticidal compounds can be identified and their effects on other biological parameters of $S$. zeamais can be evaluated.

\section{Acknowledgments}

The authors thank Fundação de Apoio ao Desenvolvimento do Ensino, Ciência e Tecnologia do Estado de Mato Grosso do Sul (FUNDECT-MS) for financial support and Conselho Nacional de Desenvolvimento Científico e Tecnológico (CNPq) for the grant awarded to the first author. They are also indebted to Ubirazilda Rezende, MSc., for identification of the plant species. 


\section{References}

Calcagno, M.P.; Coll, J.; Lloria, J.; Faini, F. \& Alonso, A.M.E. 2002. Evaluation of synergism in the feeding deterrence of some furanocoumarins on Spodoptera littoralis. Journal of Chemical Ecology 28: 175-191.

Casida, J.E. \& Quistad, G.B. 1998. Golden age of insecticide research: past, present, or future? Annu. Rev. Entomol. 43: 1-16.

Cavalcante, G.M.; Moreira, A.F.C. \& Vasconcelos, S.D. 2006. Potencialidade inseticida de extratos aquosos de essências florestais sobre mosca-branca. Pesquisa Agropecuária Brasileira 41: 9-14.

Cechinel Filho, V. \& Yunes, R.A. 1998. Estratégias para a obtenção de compostos farmacologicamente ativos a partir de plantas medicinais. conceitos sobre modificação estrutural para otimização da atividade. Química Nova 21: 99-105.

Croteau, R.; Kutcha, T.M. \& Lewis, N.G. 2000. Natural products (secondary metabolites). Pp. 1250-1317. In: B. Buchanan et al. (eds.). Biochemistry \& Molecular biology of Plants. Rockville, American Society of Plant Physiologists.

Dixon, R.A. 2001. Natural products and plant disease resistance. Nature 411: 843-847.

Dixon, R.A. \& Strack, D. 2003. Phytochemistry meets genome analysis, and beyond. Phytochemistry 62: 815-816.

Gallo, D.; Nakano, O.; Silveira Neto, S.; Carvalho, R.P.L.; Baptista, G.C.; Berti Filho, E.; Parra, J.R.P.; Zucchi, R.A.; Alves, S.B.; Vendramim, J.D.; Marchini, L.C.; Lopes, J.R.S. \& Omoto, C. 2002. Entomologia Agrícola. Piracicaba, FEALQ.

Guarim Neto, G. \& Morais, R. G. 2003. Recursos medicinais de espécies do cerrado de Mato Grosso: um estudo bibliográfico. Acta Botanica Brasilica 17: 561-584.

Isman, M.B. 2000. Plant essential oils for pest and disease management. Crop Protection 19: 603-608

Isman, M.B. 2006. Botanical insecticides, deterrents, and repellents inmodern agriculture and an increasingly regulatedworld. Annual Review of Entomology 51: 45-66.

Jardim, M.A.G.; Silva, J.C. \& Costa Neto, S.V. 2005. Fitoterapia popular e metabólitos secundários de espécies vegetais da Ilha de Algodoal, Município de Maracanã, Estado do Pará, Brasil. Resultados preliminares. Revista Brasileira de Farmácia 86: 117-118.

Larsson, S.; Lundgren, L.; Ohmart, C.P. \& Gref, R. 1992. Weak responses of pine sawfly larvae to high needle flavonoid concentrations in scots pine. Journal of Chemical Ecology 18: 271-282.

Lee, M.I.; Nishimoto, S.; Yang, L.L.; Yen, K.Y.; Hatano, T.; Yoshida, T. \& Okuda, Y. 1997. Two macrocyclic hydrolysable tannin dimers from Eugenia uniflora. Phytochemistry 44: 1343-1349.

Matsumura, T.; Kasai, M.; Hayashi, T.; Arisawa, M.; Momose, Y.; Arai, I.; Amagaya, S. \& Komatsu, Y. 2000. A-glucosidase inhibitors from Paraguayan natural medicine, Nangapiry, the leaves of Eugenia uniflora. Pharmaceutical Biology 38: 302-307.

Mazzonetto, F. \& Vendramim, J.D. 2003. Efeito de Pós de Origem Vegetal sobre Acanthoscelides obtectus (Say) (Coleoptera: Bruchidae) em Feijão Armazenado. Neotropical Entomology 32: $145-149$.
Mello, M.O. \& Silva Filho, M.C. 2002. Plant-insect interactions: an evolutionary arms race between two distinct defense mechanisms. Brazilian Journal of Plant Physiology 14: 71-81

Morimoto, M.; Tanimoto, K.; Sakatani, A. \& Komai, K. 2002. Antifeedant activity of an anthraquinone aldehyde in Galium aparine L. against Spodoptera litura F. Phytochemistry 60: 163-166

Nicholson, R.A.; Zhang, A. \& Surnagin B. 1995. Insecticidal properties and mechanisms underlying its transmitter releasing action in nerve terminal fractions isolated from mammalian brain. Pesticide Biochemistry and Physiology 53: 152-163.

Park, I.K.; Lee, H.S.; Lee, S.G.; Park, J.D. \& Ahn, Y.J. 2000. Antifeeding activity of isoquinoline alkaloids identified in Coptis japonica roots against Hyphantria cunea (Lepidoptera: Arctiidae) and Agelastica coerulea (Coleoptera: Galerucinae). Journal of Economic Entomology 93: 331-335.

Piubelli, G.C.; Hoffmann, C.C.B.; Arruda, I.C.; Franchini, J.C. \& Lara, F.M. 2003. Flavonoid increase in soybean as a response to Nezara viridula injury and its effect on insect-feeding preference. Journal of Chemical Ecology 29: 1223-1233.

Pott, A. \& Pott, V.J. 2003. Plantas do Pantanal. Corumbá, EMBRAPA-CPAP.

Saito, M.L.; Pott, A.; Ferraz, J.M.G. \& Nascimento, R.S. 2004. Avaliação da Atividade Inseticida em Espécies de Plantas do Pantanal Matogrossense. Boletim de Pesquisa e Desenvolvimento. Jaguariúna, Embrapa Meio Ambiente.

Santos, J.P.; Maia, J.D.G. \& Cruz, I. 1990. Efeito da infestação pelo gorgulho-do-milho e traça sobre a germinação de sementes de milho. Pesquisa Agropecuária Brasileira 25: 1687-1692.

Sharma, H.C. \& Norris, D.M. 1994. Biochemical mechanisms of resistance to insects in soybean: extraction and fractionation of antifeedants. Insect Science and its Application 15: 31-38.

Silva, G.; Lagunes, A. \& Rodríguez, J. 2003. Control de Sitophilus zeamais (Coleoptera: Curculionidae) com polvos vegetales solos y em mesclas com carbonato de cálcio em maiz almacenado. Ciencia e Investigacion Agrária 30: 153-160.

Simmonds, M.S.J. 2001. Importance of flavonoids in insect-plant interactions: feeding and oviposition. Phytochemistry 56: 245-252.

Strong, D.R.; Lawton, J.H. \& Southwood, T.R.E. 1984. Insects on plants: community patterns and mechanisms. Oxford, Blackwell Scientific Publications.

Tapondjou, L.A.; Adler, C.; Bouda, H. \& Fontem, D.A. 2002. Efficacy of powder and essential oil from Chenopodium ambrosioides leaves as post-harvest grain protectants against six-stored products beetles. Journal of Stored Products Research 38: 395-402.

Tavares, M.A.G.C. \& Vendramim, J.D. 2005. Bioatividade da erva-desanta-maria, Chenopodium ambrosioides L. (Chenopodiaceae) sobre Sitophilus zeamais Mots. (Coleoptera: Curculionidae). Neotropical Entomology 34: 319-323.

Van Beek, T.A. \& Breteler, H. 1993. Phytochemistry and agriculture. Oxford, Clarendon Press.

Verpoorte, R.; Van Der Heijden, R.; Ten Hoopen, H.J.G. \& Memelink, J. 1999. Metabolic engineering of plant secondary metabolite pathways for the production of fine chemicals. Biotechnology Letter 21: 467-479. 